\title{
Microbial Consortium and Enzymes Action for Rapid Composting of Urban Waste with Activators
}

\author{
Davalsab Javoor $^{1 *}$, B. Narayan Swamy ${ }^{1}$, M. K. Shivaprakash ${ }^{1}$, \\ N. Eranna ${ }^{1}$, T. Chikkaramappa ${ }^{2}$ and K. Murali ${ }^{3}$ \\ ${ }^{1}$ Department of Agricultural Microbiology, ${ }^{2}$ Department of Soil Science and Agricultural \\ Chemistry, ${ }^{3}$ AICRP on Pigeon Pea, ZARS, College of Agriculture, University of Agricultural \\ Sciences, GKVK, Bengaluru-560065, India \\ *Corresponding author
}

\section{A B S T R A C T}

\section{Keywords}

Urban waste compost, Microbial consortium, dehydrogenase, phosphatase, urease

Article Info

\section{Accepted:}

18 March 2021 Available Online: 10 April 2021
An Investigation was carried out on enzymes activity during composting of urban waste with microbial consortium and activators (cow dung slurry, diary spent wash, biodigester liquid and bovine urine). Significant variation in dehydrogenase, phosphatase and urease activity was noticed among the treatments at all the intervals during composting of urban waste with activators. Dehydrogenase activity was increased at 30th day of composting and decreased at 60th day thereafter, it gradually increased at 120th day of composting. The final stage of composting, the highest dehydrogenase activity was observed in the treatment T3 (T2+ cow dungslurry) (196 $\mu \mathrm{g}$ TPF /g soil/hour) followed by the treatment T7(T2+Bovine urine) (190.25 $\mu \mathrm{g}$ TPF /g soil/hour). The phosphatase and urease activity were found to be increased at all the intervals. The maximum acid and alkaline phosphatase activity were recorded in the treatment T7 (T2+Bovine Urine) (120 $\mu \mathrm{g}$ PNP g-1hr-1) and T3 (T2+ Cowdung slurry)

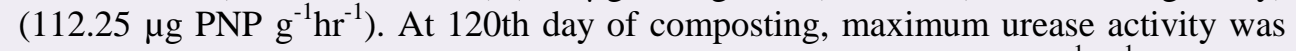
recorded in the treatment T3 (T2+ Cowdung slurry) $\left(380 \mu \mathrm{g} \mathrm{NH} 4+-\mathrm{N} \mathrm{g}^{-1} \mathrm{hr}^{-1}\right)$ followed by the treatment $\mathrm{T} 7$ (T2+ Bovine urine) $\left(376.25 \mu \mathrm{g} \mathrm{NH} 4+-\mathrm{N} \mathrm{g}^{-1} \mathrm{hr}^{-1}\right)$. The least dehydrogenase, urease, acid and alkaline phosphatase activity was in the treatment $\mathrm{T} 1$

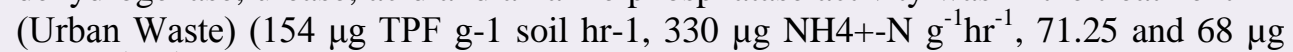
PNP g ${ }^{-1} \mathrm{hr}^{-1}$ respectively).

\section{Introduction}

The urban population in India grew at a rate of 31.8 per cent during the last decade to 377 million, which is greater than the entire population of US, the third largest country in the world according to population. The improper disposal of urban waste results in contamination of environment and spread of diseases. Management of these waste related problems has become a major impact on the nation economy. 
"Urban waste" is a term usually applied to an assorted collection of wastes produced in urban areas, the nature, characteristics and quantity of which varies from region to region. Waste generation is influenced by lifestyle of the region's inhabitants, but also by copiousness and natural resources. India is the second largest nation in the world with a population of 1.21 billion (Census of India, 2011), accounting for nearly $18 \%$ of world's human population with inadequate resources and systematic methodology to handle solid wastes. Thus, enormous generation of solid waste is being caused by such a high population growth rate posing a serious threat to environmental quality and human health (Balasubramanian \& Birundha, 2012).

In recent times, much importance is given to the composting of municipal solid wastes because of its eco-compatibility and easy operational procedures. Successful conversion of organic matter into simpler units of organic carbon and nitrogen is the basic functional process of composting. Composting helps in managing large quantities of organic wastes in a sustainable manner. It is one of the technologies of integrated waste management strategies, used for the recycling of organic materials into a useful product (Giglotti et al., 2005). In India, composting of bio-degradable wastes has been made compulsory by the Supreme Court considering the recommendations made by the Burman Committee report 1999 and the consequent MSW handling rules (2000) (CPCB, 2002).

Composting, undoubtfully, an efficient way of managing municipal solid wastes; however, disadvantages such as time and space requirement and the need for manpower are the blocking stumps for this eco-friendly technology. Shortening of composting period with considerable reduction in the $\mathrm{C} / \mathrm{N}$ ratio is one of the options considered for making the composting business lucrative one. Another intricacy in composting technology is the assessment of compost maturity. Many parameters to evaluate the maturity of compost from food wastes or city refuse, such as the change of physico-chemical properties (Mathur et al., 1993; Jiminez and Garcia, 1992), calorimetric and spectroscopic methods (De Oliveira et al., 2002), germination tests (Zucconi et al., 1985) enzymatic activity (Vuorinen, 2000) have been reported. Hue and Liu (1995) suggested using the water soluble organic-C/total organic nitrogen ratio as a suitable parameter for assessing There is a prospective potential for the bio-conversion of urban waste to enriched compost and utilization as a nutrient source. Composting is a biological decomposition of organic matter by microorganisms. During composting, the starting material is transformed through a variety of biological and biochemical processes in which enzymes play vital role Vuorinen (2000). The enzyme activities largely reflected the diversity of the microbial population and in turn reflect the composting process. The three enzymes viz., dehydrogenase, phosphatase and urease are essential in the mineralization of nutrients. The mineralization of organic $\mathrm{N}$ during composting, which involves the release of $\mathrm{N}$ from non-peptide $\mathrm{C}-\mathrm{N}$ bonds in amino acids and urea is mediated by enzymes such as amidohydrolases and dehydrogenases. Alkaline and acid phosphatases are important enzymes in organic P mineralization and plant nutrition Speir et al., (1978). Characterizing and quantifying enzymatic activities during composting can reflect the dynamics of the composting process in terms of the decomposition of organic matter and nitrogen transformations, and may provide information about the maturity of composted products Tiquia (2002). In addition, on the basis of the well demonstrated relationship between enzymatic activity and quantity and quality of organic matter it could also give information on compost stabilityGarcia et al., (2000), 
defined as the degree of decomposition of the readily bio-degradable organic matter Lasaridi and Stentiford (1998). With this context the present study was conducted on "Enzyme's activity during composting of urban waste with microbial consortium and activators.

\section{Materials and Methods}

Compost was prepared in plastic covered pit of $100 \mathrm{~cm} \times 60 \mathrm{~cm} \times 100 \mathrm{~cm}$ (Length x Width $\mathrm{x}$ Height). The urban waste was mixed with activators in 2:1 ratio layer by layer, and microbial consortium (Trichoderma harzianum, Penicillium polonicum, Coprinus spp, Bacillus cereus, Bacillus licheniformis and Streptomyces albus) was added to each layer at the rate of $2.5 \mathrm{~L}$ per ton of substrate to improve the efficiency of composting as per treatment structure. Finally, the composting material was completely covered with soil slurry at the top in order to prevent the heat loss and emission of odor. Composting material was turned regularly once in 15 days to ensure aeration and water was added regularly to maintain the moisture approximately 60 per cent of maximum water holding capacity. The composting experiments were carried out in the Department of Agricultural Microbiology, UAS, GKVK, Bengaluru with following treatment combinations.

\section{Treatment detail}

T1: Urban Waste

$\mathrm{T} 2$ : $\mathrm{T} 1+$ microbial consortium

T3: T2+ Cow dung Slurry

T4: T2+ Diary Spent Wash

T5: T2+ Poultry Slurry

T6: T2+ Biodigester Liquid
T7: T2+ Bovine Urine

The design adopted was completely randomized block design (CRD) with seven treatments and four replications.

\section{Sample collection}

During composting, samples were collected at different intervals (30, 60, 80 and 120 days) from each pit (from four sides and one from center) using spiked augers. The samples were pooled in each treatment and composite samples were analyzed for enzyme activities by following the standard procedures.

\section{Dehydrogenase activity}

Dehydrogenase activity in the samples was determined by following the procedure described by Casida et al., (1964). Five grams of sample was thoroughly mixed with $0.2 \mathrm{~g}$ of $\mathrm{CaCO}_{3}$ and transferred to test tubes. One $\mathrm{ml}$ of 1.5 per cent aqueous solution of 2,3,5triphenyl tetrazolium chloride (TTC) was added to each tube. One $\mathrm{ml}$ of 1 per cent glucose solution and $8 \mathrm{ml}$ of distilled water was added in such a way that it should form a thin film of water just above the sample layer.

The tubes were stoppered and incubated at $300 \mathrm{C}$ for 24 hours. At the end of incubation, the contents in the tube were rinsed down into a small beaker through Whatman No.15 filter paper. Repeated rinsing of sample with methanol was continued till the filtrate ran free of red color. The volume of the filtrate was made up to $50 \mathrm{ml}$ with methanol in a volumetric flask. The intensity of red color was measured at $485 \mathrm{~nm}$ against a methanol blank using UVVIS Spectrophotometer. The concentration of formazan formed in samples was determined by using graded concentrations of formazan. The results were expressed as microgram of triphenylformazan (TPF) formed per gram of sample per day. 


\section{Phosphatase activity}

Phosphatase activity of samples was determined by following the standard procedure of Eivazi and Tabatabai (1977). One gram of sample was placed in $50 \mathrm{ml}$ Erlenmeyer flask in 2 sets of which $0.2 \mathrm{ml}$ toluene followed by $4 \mathrm{ml}$ of modified universal buffer $(\mathrm{pH} 6.5$ for acid phosphatase and $\mathrm{pH} 11.00$ for alkaline phosphatase) was added to the flasks and contents of the flasks were mixed by swirling for 2 minutes. The flasks were stoppered and incubated at $37^{\circ} \mathrm{C}$ for 1 hour. After incubation, $1 \mathrm{ml}$ of $0.5 \mathrm{M}$ $\mathrm{CaCl}_{2}$ and $4 \mathrm{ml}$ of $0.5 \mathrm{M} \mathrm{NaOH}$ were added to the flask, swirled and filtered through Whatman No. 42 filter paper. The intensity of yellow color developed was measured at 420 $\mathrm{nm}$ against the reagent blank using UV-VIS spectrometer. Control was performed following the same procedure described above, except that the paranitrophenyl phosphate solution was added after the addition of $0.5 \mathrm{M} \mathrm{CaCl}_{2}$ and $0.5 \mathrm{M} \mathrm{NaOH}$ and just before filtration. The phosphatase activity in the samples was expressed as $\mu \mathrm{g}$ para-nitro phenol $\mathrm{g}^{-1} \mathrm{~h}^{-1}$ of sample with reference to the standard curve prepared by using graded concentrations of para-nitrophenol solution.

\section{Urease activity}

The urease activity was estimated by following the method outlined by Eivazi and Tabatabai (1977). Two grams of sample was taken in a $50 \mathrm{ml}$ Erlenmeyer flask and treated with $0.2 \mathrm{ml}$ of toluene and $9 \mathrm{ml}$ of THAM buffer and flasks were swirled for few seconds to mix the contents properly. One $\mathrm{ml}$ of $0.2 \mathrm{M}$ urea was added and the flasks were swirled for few seconds and placed in an incubator at 370 C. The stoppers were removed after 2 hours and approximately $35 \mathrm{ml}$ of $\mathrm{KCl}-\mathrm{Ag}_{2} \mathrm{SO}_{4}$ solution was added. The flasks were swirled again and allowed to stand until the contents have cooled to the room temperature. The volume was then made up to $50 \mathrm{ml}$ by adding $\mathrm{KCl}-\mathrm{Ag}_{2} \mathrm{SO}_{4}$. The NH4-N was estimated by steam distillation. Controls were performed in the same way, but $1 \mathrm{ml}$ of $0.2 \mathrm{M}$ urea was added after the addition of $35 \mathrm{ml}$ of $\mathrm{KCl}$ $\mathrm{Ag}_{2} \mathrm{SO}_{4}$ solution. The urease activity in the samples was expressed as $\mu \mathrm{g}$ NH4-N/g soil/hour.

\section{Results and Discussion}

Enzymes activity during composting of urban waste with microbial consortia and activators. Dehydrogenase activity

The dehydrogenase activity during composting of urban waste with microbial consortium and activators showed significant variation among the treatments during all the intervals (Table 1). The activity of dehydrogenase enzyme was higher at 30th day of composting and then decreased up to 60th day of decomposition and there after it increased up to 120th day of composting in all the treatments at all the intervals. At the final stage of composting, the highest dehydrogenase enzyme activity was observed in the treatment $\mathrm{T} 3$ (T2+ Cow dung Slurry) (196 $\mu \mathrm{g}$ TPF /g soil/hour) followed by the treatment T7 (T2+Bovine Urine) (190.25 $\mu \mathrm{g}$ TPF /g soil/hour) and was significantly higher compared to all other treatments while the least enzyme activity was recorded in the treatment T1 (Urban waste) alone (154 $\mu \mathrm{g}$ TPF g-1 soil hr-1). Dehydrogenase is an intracellular enzyme which is usually involved in microbial oxido-reductase metabolism and its activity was found to be highest in compost than in soil Garcia et al., (1993). The dehydrogenase enzyme activity basically depends on the metabolic state of microbes and widely used to measure the metabolic activities, which in turn correlated with total microbial activity. In the present study, there was higher dehydrogenase activity in all the treatments during initial days and then 
decreased noticeably up to 60th day and thereafter again it increased up to 120th day. This could be due to presence of higher amount of available nutrients and organic carbon content during earlier period of decomposition. It is suggested that carbon is one of the factors stimulating activity of the enzyme by Zantan and Bremmer (1976). Similar kinds of results were also reported by Pedrazzini and McKee (1984) and Saviozzi et al.,(2004).

\section{Acid and alkaline phosphatase activity}

The data on acid and alkaline phosphatase activity showed significant differences among the treatments at all the intervals during the process of composting of urban waste with microbial consortium and activators (Table 2). There was an increase in both the enzymes activity throughout the period of degradation. The maximum acid and alkaline phosphatase activity were recorded on 120th day of decomposition and was in the treatment $\mathrm{T} 7$ (T2+Bovine Urine) $(120 \mu \mathrm{g}$ PNP g-1hr-1) and T3 (T2+ Cow dung slurry) (128 $\mu \mathrm{g}$ PNP g1hr-1) and are significantly higher when compared to all other treatments whereas, the least enzyme activity was observed in T1 (Urban waste) (71.25 and $68 \mu \mathrm{g}$ PNP g-1hr-1 respectively). Phosphatase plays an important role in transforming the organic phosphorus into the available form of phosphorus Pedrazzini and Mckee (1984).

The phosphatase activity is due to the presence of phosphorylated compounds, which act as a substrate for the microorganisms to synthesize phosphatase and is considered as general microbial indicator Spier and Ross (1978). In the present study both the enzymes activities in all the treatments were higher during thermophilic phase of decomposition. It is quite possible that addition of urban waste which is rich in nutrients to a material containing high organic carbon resulted in rapid decomposition due to higher activity of heterotrophic microorganisms which were dominant and results in depletion of available phosphorous for the growth of microorganisms which induced them to liberate extracellular phosphatase for mineralization of organic phosphorous. The results obtained are in confirmation with the findings of Senthilraja (2007) who also reported the enhanced phosphatase enzyme activities during the composting of pressmud fiber. The increase in phosphatase activity might be attributed to higher temperature and higher bacterial population Chonkar and Tarafdar (1984).

\section{Urease activity}

The results obtained on urease activity showed significant variations among different treatments at all the intervals during the process of composting (Table 3 ). There was an increase in urease activity throughout the period of composting. At 120th day of composting, maximum urease activity was recorded in the treatment $\mathrm{T} 3(\mathrm{~T} 2+$ Cowdung

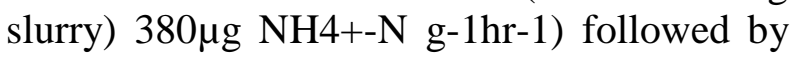
the treatment $\mathrm{T} 7$ (T2+ Bovine urine) (376.25 $\mu \mathrm{g}$ NH4+-N g-1hr-1) and which was significantly higher compared to all other treatments. However, the least urease activity observed in treatment T1 (Urban waste) alone (330.25 $\mu \mathrm{g}$ NH4+-N g-1hr-1). The enzyme urease is responsible for breakdown of urea into $\mathrm{CO} 2$ and $\mathrm{NH} 3$. The higher urease activity may probably due to availability of easily degradable substances and higher content of nitrogen in the raw materials used, which would have stimulated microbial activity and, as a consequence, higher urease activity was found. Similar observations were also recorded by Wang (2004), Pallab De et al., (1990), Frankken and Dick (1982), and Skujins (1967). 
Table.1 Changes in dehydrogenase activity during composting of urban waste with microbial consortium and activators

\begin{tabular}{|c|c|c|c|c|}
\hline \multirow{2}{*}{ Treatments } & \multicolumn{4}{|c|}{$\begin{array}{c}\text { Dehydrogenase activity } \\
\left(\boldsymbol{\mu g} \mathbf{T P F} \mathbf{g}^{-\mathbf{1}} \mathbf{h r}^{-\mathbf{1}}\right)\end{array}$} \\
\cline { 2 - 5 } & $30 \mathrm{DAC}$ & $60 \mathrm{DAC}$ & $90 \mathrm{DAC}$ & $120 \mathrm{DAC}$ \\
\hline T1:Urban Waste & $130.75^{\mathrm{c}}$ & $108,50^{\mathrm{d}}$ & $143.50^{\mathrm{d}}$ & $154.00^{\mathrm{e}}$ \\
\hline T2:T1+microbial consortium & $139.50^{\mathrm{b}}$ & $125.50^{\mathrm{b}}$ & $154.75^{\mathrm{c}}$ & $166.00^{\mathrm{d}}$ \\
\hline T3:T2+Cowdung Slury & $146.50^{\mathrm{a}}$ & $132.00^{\mathrm{a}}$ & $172.25^{\mathrm{a}}$ & $196.00^{\mathrm{a}}$ \\
\hline T4:T2+DiarySpent Wash & $133.00^{\mathrm{c}}$ & $118.00^{\mathrm{c}}$ & $148.00^{\mathrm{d}}$ & $155.5^{\mathrm{e}}$ \\
\hline T5:T2+PoultrySpent wash & $142.00^{\mathrm{ab}}$ & $129.00^{\mathrm{ab}}$ & $163.00^{\mathrm{b}}$ & $189.00^{\mathrm{b}}$ \\
\hline T6:T2+Biodigester Liquid & $141.00^{\mathrm{ab}}$ & $127.00^{\mathrm{ab}}$ & $159.00^{\mathrm{bc}}$ & $180.25^{\mathrm{c}}$ \\
\hline T7:T2+Bovine Urine & $144.50^{\mathrm{ab}}$ & $129.00^{\mathrm{ab}}$ & $170.00^{\mathrm{a}}$ & $190.00^{\mathrm{ab}}$ \\
\hline
\end{tabular}

Note: Mean values followed by the superscript in each column do not differ significantly at $\mathrm{P}=0.05$ level by DMRT. DAC- Days after composting

Table. 2 Changes in acid and alkaline phosphatase activity during composting of urban waste with microbial consortium and activators

\begin{tabular}{|c|c|c|c|c|c|c|c|c|}
\hline \multirow[t]{2}{*}{ Treatments } & \multicolumn{4}{|c|}{$\begin{array}{l}\text { Acid phosphatase } \\
\text { ( } \mu \text { g PNP g-1hr-1) }\end{array}$} & \multicolumn{4}{|c|}{$\begin{array}{l}\text { Alkaline phosphatase } \\
\text { ( } \mu \text { g PNP g-1hr-1) }\end{array}$} \\
\hline & 30DAC & 60DAC & 90DAC & 120DAC & 30DAC & 60DAC & 90DAC & $120 \mathrm{DAC}$ \\
\hline T1 & $55^{\mathrm{e}}$ & $59.25^{\mathrm{e}}$ & $65.0^{d}$ & $71.25^{\mathrm{e}}$ & $60.0^{d}$ & $61.25^{\mathrm{a}}$ & $63.50^{\mathrm{f}}$ & $68.0^{\mathrm{d}}$ \\
\hline T2 & $60^{d e}$ & $65.0^{\mathrm{de}}$ & $70.0^{\mathrm{d}}$ & $74.50^{\mathrm{de}}$ & $69.0^{c}$ & $73.0^{\mathrm{d}}$ & $75.0^{\mathrm{e}}$ & $79.75^{\mathrm{c}}$ \\
\hline T3 & $79^{\mathrm{a}}$ & $83.50^{\mathrm{a}}$ & $87.75^{\mathrm{ab}}$ & $112.25^{\mathrm{a}}$ & $93.25^{\mathrm{a}}$ & $108.0^{\mathrm{a}}$ & $117.0^{\mathrm{a}}$ & $128.0^{\mathrm{a}}$ \\
\hline T4 & $62^{\mathrm{cd}}$ & $71.0^{\mathrm{cd}}$ & $79.0^{c}$ & $82.25^{\mathrm{cd}}$ & $80.75^{b}$ & $88.0^{c}$ & $101.25^{\mathrm{c}}$ & $103.0^{\mathrm{b}}$ \\
\hline T5 & $73.50^{\mathrm{ab}}$ & $78.50^{\mathrm{ab}}$ & $80.75^{\mathrm{bc}}$ & $97.75^{b}$ & $86.0^{\mathrm{ab}}$ & $98.0^{\mathrm{b}}$ & $107.0^{\mathrm{bc}}$ & $125.0^{\mathrm{a}}$ \\
\hline T6 & $67.50^{b}$ & $76.0^{\mathrm{bc}}$ & $79.25^{\mathrm{c}}$ & $88.50^{\mathrm{bc}}$ & $84.0^{\mathrm{b}}$ & $86.0^{c}$ & $92.75^{\mathrm{d}}$ & $96.0^{\mathrm{b}}$ \\
\hline T7 & $80.0^{\mathrm{a}}$ & $85.0^{\mathrm{a}}$ & $89.25^{\mathrm{a}}$ & $120.0^{\mathrm{a}}$ & $92.0^{\mathrm{a}}$ & $88.60^{\mathrm{a}}$ & $109.0^{b}$ & $126.0^{\mathrm{a}}$ \\
\hline
\end{tabular}

Note: Mean values followed by the superscript in each column do not differ significantly at $\mathrm{P}=0.05$ level by DMRT.

DAC- Days after composting

Table.3 Changes in the urease activity during composting of urban waste with microbial consortium and activators

\begin{tabular}{|c|c|c|c|c|}
\hline \multirow{2}{*}{ Treatment } & \multicolumn{4}{|c|}{ Urease $\left(\boldsymbol{\mu g} \mathbf{N H}_{\mathbf{4}}+\mathbf{-} \mathbf{N ~}^{-\mathbf{1}} \mathbf{h r}^{\mathbf{- 1}}\right)$} \\
\cline { 2 - 5 } & $30 \mathrm{DAC}$ & $60 \mathrm{DAC}$ & $90 \mathrm{DAC}$ & $120 \mathrm{DAC}$ \\
\hline T1: Urban Waste & $230.0^{\mathrm{b}}$ & $290.0^{\mathrm{c}}$ & $299.0^{\mathrm{d}}$ & $330.25^{\mathrm{cd}}$ \\
\hline T2:T1+microbial consortium & $232.0^{\mathrm{ab}}$ & $293.0^{\mathrm{bc}}$ & $312.0^{\mathrm{c}}$ & $340.0^{\mathrm{bc}}$ \\
\hline T3:T2+Cowdung Slury & $245.0^{\mathrm{a}}$ & $320.0^{\mathrm{a}}$ & $339.75^{\mathrm{a}}$ & $380.0^{\mathrm{a}}$ \\
\hline T4:T2+Diary Spent Wash & $235.0^{\mathrm{ab}}$ & $301.0^{\mathrm{b}}$ & $316.0^{\mathrm{c}}$ & $325.0^{\mathrm{d}}$ \\
\hline T5:T2+Poultry Slury & $241,0^{\mathrm{ab}}$ & $319.0 \mathrm{a}$ & $328.75^{\mathrm{b}}$ & $349.0^{\mathrm{b}}$ \\
\hline T6:T2+Biodigester Liquid & $238.0^{\mathrm{ab}}$ & $301.5^{\mathrm{b}}$ & $319.0^{\mathrm{c}}$ & $328.0^{\mathrm{d}}$ \\
\hline T7:T2+Bovine Urine & $242.25^{\mathrm{ab}}$ & $316.0^{\mathrm{a}}$ & $335.0^{\mathrm{ab}}$ & $376.25^{\mathrm{a}}$ \\
\hline
\end{tabular}

Note: Mean values followed by the superscript in each column do not differ significantly at $\mathrm{P}=0.05$ level by DMRT.

DAC- Days after composting 
They reported that increased urease activity during composting process could be due to higher organic carbon and total nitrogen content which resulted in higher microbial activity.

The present study dictates that enzymatic activities can be considered as a descriptor of the biological catalyst for organic wastes. The efficient microbial consortium plays a major role in enhancing the degradation process and it can be used for hastening the process of urban waste composting with activators. The enzyme activities found maximum in the treatment received urban waste with cow dung slurry and bovine urine. Hence, urban waste, cow dungslurry and bovine urine activators combination is ideal for composting and enhance quality of matured compost.

\section{References}

Anonymous, 2011, Census of India (2011). Office of the registrar General and Census Commissioner, India Ministry of home affairs, Government of India: 27.

Benito, M., Masaguer, A., Moliner, A., Arrigo, N., and Palma, R.S., 2003, Chemical and microbiological parameters for the characterization of the stabilizing and maturing of pruning waste compost. Biol. Fert. Soils, 37: 184-189.

Casida, L. E., Klein, D. A. and Snatoro, T., 1964, Soil dehydrogenase activity. Soil Sci.,98: 371-376.

Chonkar, P. K. and Tarafdar, J. C., 1984, Accumulation of phosphatases in soil.J. Indian Soc. Soil Sci.,132: 266272.

CPCB, 2002, Central Pollution Control Board, Management of Municipal Solid Wastes, New Delhi, India.

De Oliveira, S.C., Provenzano, M.R., Silva, M.R.S., and Senesi, N., 2002, Maturity degree of composts from municipal solid wastes evaluated by differential scanning calorimetry. Environ. Technol.,23: 1099-1105.

Frankken, B. W. T. and Dick. W. A., 1982, Relationships between enzyme activities during composting of waste microbial biomass from pharmaceutical industry. Acta.Chim. Slov.,49: 885-892.

Garcia, C., Hernandez, T., COSTA, F., Ceccanti, C.and Ganni, A., 1993, Hydrolases in organic matter fractions of sewage sludge: changes in composting. Biores. Technol.,44: 1723.

Garcia, J. C., Plaza, C., Rovira, P. S. And Polo, A., 2000, Long term effects of municipal solid waste compost application on soil enzyme activities and microbial biomass. Soil Biol. Biochem.,32: 1907-1913.

Giglotti, G., Valentini, F., Erriquens, F.G., and Said-Pullicino, D., 2005, Evaluating the efficiency of the composting process: a comparison of different parameters. Geophys. Res. Abs., 7: 09606.

Hue, N.V., and Liu, J., 1995, Predicting compost stability. Compost Sci. Util., 3: 8-15.

Jiminez, E.I., and Garcia, V.P., 1992, determination of maturity indices for city refuse composts. Agr.Ecosyst. Environ., 38: 331-343.

Lasaridi, K.E. and Stentiford, E.I., 1998, A simple respirometric technique for assessing compost stability. Water Res., 32: 3717-3723.

Mathur, S.P., Dinel, H., Owen, G., and SCHNITZER, M., 1993, Determination of compost bio maturity I. literature review. Biol. Agr. Hortic., 10: 65-85.

Muniyandi Balasubramanian and Birundha, V., 2012, Climate change and its 
impact on India. J. Environ. Sci.,4(1):31-46

Pallab DE, K., Arun, K. and De, S.K., 1990, Soil enzymes: Activities and agricultural importance. Ind. J. Agril. Chem.,22(2): 223-224.

Pedrazzini, F. R. and Mckee, K. L., 1984, Effect of flooding on activities of soil dehydrogenase in rice. Soil Sci. Plant Nutri.,30(4): 359-365.

Saviozzi, A., Cardelli, R., LEVI -MINZI, R. and Riffaldi, R., 2004, Evolution of biochemical parameters during composting of urban wastes.Compost Sci. Util., 12(2): 153-160.

Senthilraja, K., 2007, Formulation of suitable microbial consortium for composting and value addition of press mud fiber. M.Sc. Thesis, TNAU, Coimbatore, Tamil Nadu, India.

Skujins, J., 1967, Enzymes in soil. In: Soil biochemistry (Eds.) A.D. McLaren and G. H. Peterson Marcel Dekker, New
York,4(4):371- 414.

Spier, T.W. and Ross, D. J., 1978, Soil phosphatase and sulphatase.In: Burns, R.G. (ed.). Soil Enzymes. Academic Press, New York, 197-250.

Tiquia, S. M., 2002, Evolution of extracellular enzyme activities during manure composting. J. Appl. Microbiol., 92(4): 764-775.

Vuorinen, A. H., 2000, Effect of bulking agent on acid and alkaline phosphormonoesterase and D-glucosidase activities during manure composting. Biores. Technol.,75: 113-138.

Wang, C.M., Changa, C.M., Watson, M.E., Dick, W.A., Chen, Y., and Hoitink, H.A.J., 2004, Maturity indices of composted dairy and pig manures. Soil Boil. Biochem., 36: 767-776.

Zantan, M. L. and Bremmer, J. M., 1976, Comparison of method of assaying urease activity in soils. Soil Biol.Biochem., 7: 1291-1295.

\section{How to cite this article:}

Davalsab Javoor, B. Narayan Swamy, M. K. Shivaprakash, N. Eranna, T. Chikkaramappa and Murali, K. 2021. Microbial Consortium and Enzymes Action for Rapid Composting of Urban Waste with Activators. Int.J.Curr.Microbiol.App.Sci. 10(04): 544-551. doi: https://doi.org/10.20546/ijcmas.2021.1004.053 